соколовА Алла Николаевна доктор искусствоведения, профессор кафедры теории, истории музыки и методики музыкального воспитания

Института искусств

Адыгейского государственного университета, Майкоп, Российская Федерация Alla N. SOKOLOVA Dr. Sci. (Musical Art), Prof., Institute of Arts, Adyghe State University, Maykop, Russian Federation, professor_sokolova@mail.ru

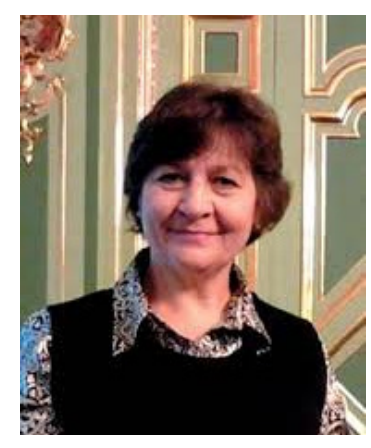

УДК [75-051(=352.3)(470.621)+75-051(=352.3)(560)]:303.446.23

DOI: 10.36343/SB.2020.24.4.003

ГРНТИ 18.31.91

ВАК 24.00.01

\section{Общее и особенное в творчестве черкесских художников Адыгеи и черкесов Турции ${ }^{1}$}

\author{
Similarities and Differences \\ in Oeuvre of Circassian Artists \\ of Adygea and Circassians of Turkey ${ }^{2}$
}

Исследование призвано выявить и проанализировать общие и особенные характеристики творчества черкесских художников Адыгеи их коллег из адыгской диаспоры Турции. Источниками послужили произведения изобразительного искусства, результаты исследований отечественных и турецких искусствоведов, критиков, социологов и историков. Методология опирается на сочетание компаративных приемов, применяемых в искусствоведении для анализа художественных объектов и систем (синхронный и диахронный методы, микро- и макросравнение). Изучена общественная функция мастеров живописи, живущих в разных социокультурных условиях, выявлены цели их творчества, проанализированы приоритетные жанры и приемы. Подчеркнуто значение адыгских художников, живших и живущих на Северном Кавказе, как представителей художественной элиты этноса, при этом их творчество направлено на сохранение мифопоэтических образов и этнической идентичности. Иные тенденции выявлены в творческом опыте черкесских художников Турции, которые стремились не только и не столько раскрывать культуру своего народа, сколько обращались к универсальным ценностям, пытаясь интегрироваться в систему европейского и мирового искусства. Автор выделяет два периода развития изобразительного искусства черкесских художников России и Турции: до распада СССР и после него. Выявляются характерные черты творчества представителей обеих групп художников на протяжении выделенных периодов. Особо выделена деятельность современ-

1 Статья написана при финансовой поддержке РФФИ, проект 20-012-00065 «Культурные диффузии черкесов Турции и России: искусствоведческий и социокультурный анализ».

2 This work was supported by the Russian Foundation for Basic Research, Project No. 20-012-00065: Cultural Diffusion of the Circassians of Russia and Turkey: Art History and Socio-Cultural Anslysis. 
ных художников-рецептуалистов адыгского происхождения (Р. Цримова и А. Гучапшева и др.). Приведены основные художественные принципы рецептуализма, и в сравнительном аспекте выявлена степень известности этого направления в Кабардино-Балкарии и Адыгее. Делается вывод, что различия между адыгскими художниками России и Турции проявлялись в нескольких аспектах: в моменте формирования адыгских художественных сообществ в Турции и в России; в особенностях сформировавшейся и поддерживавшейся художественной традиции; в неравных условиях получения профессионального образования мастерами Кавказа и Турции; в социально-экономических обстоятельствах, определявших творческую деятельность и косвенно повлиявших на ценностные ориентации художников. Точки творческого пересечения лежат в плоскости этнических ценностей, знаков и символов, одинаково расшифрованных черкесами Северного Кавказа и диаспоры, а также в оценках исторического прошлого, особенно Кавказской войны, в особо почитаемом отношении к природе и красотам Кавказа.

Ключевые слова: адыги, черкесы, столичные художники, диаспора, картина мира, роли художников, знаки и символы искусства, эстетические доминанты, приоритетные жанры, сходство и различие в творчестве черкесских художников.

Introduction. The artwork of the Circassian artists of Russia and of the Adyghe diaspora of Turkey is a poorly studied phenomenon. Neither roles of the artists nor functions of their art, nor basic artistic rules and styles predominant in their oeuvre are determined. The world, as well as Russia, does not have a sufficiently complete idea about artistic processes taking place in the North Caucasus. Equally closed to the Russian public is knowledge about artistic processes taking place in the environment of the multi-million Adyghe diaspora in Turkey. This raises the questions of practical and theoretical planes. Some of them are related to the topic of the article indirectly, but without discussing them the issue cannot be explored. Does modern regional art exist? What criteria is it measured by? Does modern ethnic art exist in the conditions of globalization and postmodernity? Do the Circassians, land-wise separated and living in different cultural environment in different economic, ideological and political circumstances, preserve a similar worldview reflected in the artistic consciousness of the creative elite? What is the content of the concept "regional aesthetics"?

The outlined array of questions characterizes the issue in the investigation of the modern art of not only the Circassians (Adyghes), but also many other North Caucasian peoples, which updates the ongoing research supported by the Russian Foundation for Basic Research.
The aim of the research is to identify similarities and differences inherent in the oeuvre of the Adyghe artists of the Caucasus and of Turkey by analyzing the subject areas and artistic images, social functions of artists that live in different sociocultural conditions, their creative goals, preferred genres and artistic techniques.

The research uses the results of studies by Russian (including North Caucasian) and Turkish art critics and historians, paintings by Adyghe artists.

The methodological basis of the research was a set of comparative techniques used in art criticism and art history to study the development of art objects and systems (synchronic and diachronic methods, micro- and macro-comparison).

Research in the fields of understanding the processes occurring in society and nature, of social relations, of establishment and development of artistic values and aesthetic dominants is interesting not only separately but also with regard to the understanding of the extent to which culture is permeable to external influence and of what the impermeable in the history of the culture core is that allows ethnic groups to preserve themselves even in unfavorable conditions.

Excerpts on the history of the establishment of professional pictorial art. It is commonly known that pictorial art was not introduced in the traditional culture of the Adyghes (Circassians). Some scholars explain the lack of fine art 
among the Adyghes in the pre-Soviet period by the confession of Islam or the specificity of the artistic thinking of the highlanders, who embodied art in a decorative form [2] [5]. The professional art of painting among the Russian Circassians appeared in Soviet times on the basis of applied arts and finally took shape by the middle of the 20th century, when artists with professional degrees in art received in the capital cities of the USSR (Moscow, Leningrad, Tbilisi) appeared in the republics of the North Caucasus and, in particular, in Adygea. The policy of the Soviet state to represent each major ethnic group through artistic culture "pushed" the leadership of the republics and autonomies to organize creative unions, form artistic elites, select talented young people and train them in the best creative universities in the country. Thus, in 1957 more than ten young people with beautiful voices were selected from auls of Krasnodar Krai and sent to study in Leningrad Conservatory (G. Samogova, R. Panesh, R. Sheozhev, K. Kheyshkho, Sh. Akhidzhak, and others).

Davlet Meretukov (1929-2000), after his military service in the Soviet Army, entered Moscow Art College n.a. 1905, after that he studied at the Surikov Art Institute in Moscow. Felix Petuvash (born in 1948), at the age of 12, went to Moscow to study in a secondary school at the Surikov Art Institute, and then he entered the Stroganov Moscow State Academy of Arts and Industry. Abdullah Bersirov (born in 1947) graduated from the Architecture Faculty of the Ilya Repin St. Petersburg State Academic Institute of Fine Arts, Sculpture and Architecture. Nurbiy Didichev (1950-2001) and Teuchezh Kat (born in 1945) graduated from Tbilisi Art Academy. Almost all painters, professionally educated, had state orders for monumental works on a regular basis; were members of the professional Artists Trade Union of the USSR; and were given corresponding social and creative advantages. These artists were not only provided with work but also given vouchers to the House of Creativity, studios and materials for work. Naturally, the orders made by professional artists pursued the interests of the authorities and the state.

The fate of the artistic elite of the Circassians in Turkey was quite different. First of all, the national policy of Kemalists did not allow ethnic determination of the people. All people living in Turkey claimed to be Turkish with cor- responding names and surnames. Secondly, the secular state paradigm demanded the authorities to build up the artistic elite correspondingly. In the late 19th and early 20th centuries, Turkish youth received an opportunity to study at the best universities and academies of Europe; that is why many talented artists of Circassian origin in Turkey received education in Paris, Rome, and in other European cities. Namık İsmail (1890-1935) studied at Cormon's studio in Paris (1912-1914); Ihsan Shurdom (born in 1930) studied in Rome's Central University of Restoration with a scholarship of the Government of Italy; Cihat Aral (born in 1940) had a state scholarship for studying in France; Mustafa Şener (born in 1945) lived and worked in the Netherlands for a long time and performed orders of the municipality of Amsterdam; Ahmet Özel (born in 1960) also had a state scholarship for studying in Rome and Florence; Feride Benigioğlu (born in1963) studied at Zalzburg Summer Academy and had a scholarship of Austrian government, etc. There is no doubt that talented youth had an opportunity to acquire a sound academic background at educational institutions of the USSR, though the possibilities of Turkish students in art institutions were much wider. They traveled; became acquainted with original masterpieces of world art, not their replicas; met with "necessary people", and received interesting proposals. In the conditions of the Iron Curtain, the USSR artists were deprived of such opportunities.

Thus, the starting conditions for the learning environment of Circassian artists in Russia and in Turkey are strikingly different. It is natural that the place, type and conditions of learning affected the topics, images, genre and style Turkish and Russian artists chose.

Pictorial art content. For the Circassian artists of the USSR, the Soviet ideology aiming at creating art "national in form and international in content" unambiguously directed artists to create national art, to form associations with a "national face". Reliance on folklore, ethnic mythology and epic, traditional values were recommended and encouraged. Perhaps, that is why, with all the difference in artistic style, techniques, choice of genres and stylistic orientation, all the artists of Adygea were realists. Almost all of them, in varying degrees, used Nart epic characters [10] [11]. 
Denying socialist realism as an ideologically imposed stylistic trend, the Circassian artists adopted its important feature - the idealization of the depicted. For many of them, the past was an ideal picture representing адыгагъэ (Adygheanship) and its main characteristics - адыгэ хабзэ (Adyghe etiquette), адыгэ нэмыс (Adyghe honor), адыгэ напэ (Adyghe conscience), and others.

While it was considered reprehensible to put the national above the Soviet and socialist and the country declared the formation of a new identity - the Soviet people, it was the artists in graphics, book illustrations, mosaics and, less often, in paintings that reminded of the original Adyghe values: traditions of respect for the elders, special reverence for women, and of the norms of ritual behavior as rigid values and laws, the observance of which builds up the Adyghe person.

Hence, images of the past or mythological subjects prevail in the art of Russian Circassians in comparison with images of the present or the future. The authorities in every possible way encouraged works related to national themes. Felix Petuvash was awarded a State Prize for a series of graphic sheets devoted to Nart epic (the series was created in the 1970s; the Prize was awarded in 2007); Davlet Meretukov illustrated seven volumes of the Adyghe epic Narts (1970s).

The so-called Adyghe Calendar of Ablullah Bersirov, G. Abredzh, A. Kuanov, M. Tuguz, T. Kat got a wide response; the majority of Adyghe artists and graphic artists turned to the images of the mythological or historical past as to an ideal picture of their ancestors' life. They all too often perceived the future as a return to traditional values, which were gradually forgotten or replaced by new Soviet ones.

The special influence of mythology and folklore spread not only through pictorial art, but almost through all modern art processes. It is suffice to mention the concert program Nart Symphony of the composer Aslan Nekhay, gobelin tapestries of Mukharbiy Gogunokov, symbolic dresses of Yuri Stash and others. The artists try to tell about all Nart epic heroes in different art genres, to illustrate their achievements, to convey visually their valuable characteristics and perception of the world [3].

The geography of origin and residence in the Caucasus penetrates so deeply into the artistic consciousness of creative people that the poetization of the nature of the North Caucasian region, the appeal to mythological and fairy-tale characters of Adyghe folklore become the norm not only for ethnic Adyghes, but also for artists of other nationalities: "Almost all the artists living in the Republic of Adygea think through 'Caucasian' images, they use Adyghe traditional plots, plastics, typical range of colors. They start to present themselves as people of this region, directly or indirectly associated with Adyghe (Circassian) culture, creating for the contemporaries, meeting their demands in line with their values" [13, p. 256].

Ideology of the Circassian artists of Turkey. On the contrary, the ideology of the Circassian artists of Turkey was dominated by the motive of individualization, the search for their own self, the desire to integrate in a certain way into the system of values of Turkey and Europe.

The Turkish artist of Circassian origin Ahmet Özel believes that it is not possible to speak about the Circassian diaspora's art that is based on shared ethnicity exclusively [9, p. 197]. He is convinced that the origin of the artists was not and cannot be the reason for their artistic and stylistic unity. Özel believes that "an artist should reflect not only cultural and mythological wealth of his peoples, but also should reflect the values of the place he was born in" [9, p. 198]. He forewarns that "the art works reflecting only the grief and the dream about the Caucasus have the reverse side. They involve involuntary act of hammering against the society in which they exist. Such artworks do not find their addressee in the country of residence" [9, p. 198]. Özel, who organized 18 personal exhibitions, has his own studios in Istanbul and in Spain, and is a practicing teacher, actually reflects the opinion of the whole Circassian artistic elite of Turkey.

In the opinion of the artist, whose paintings were exhibited at art venues of Moscow, Tokyo, Madrid (in seven countries totally), contemporary artists, regardless of their ethnic background, must send their messages to the world and therefore speak a universal language: "The language and expression towards the historical homeland serve only to reduce our connection with the outside world and strengthen the walls between us and outside world. To be visible and to be able to assert our existence in a universal dimension, we 
must share our unique values that exist within us with art and artists in other regions" [9, p. 198].

The question of national art school for-

mation. Perhaps, not everyone will agree with Ahmet Özel's statement. The history of the USSR was associated with the idea of national cultural development. Even now the issue of national art school existence is still pending. For example, the art expert Nurbiy Lovpache recognizes the existence of such a school, and its feature is sets of three colors ("tricolor"), different for each artist. However, when Lovpache turns to proofs, he constantly makes a reservation that this or that artist is not limited to only three colors [6]. F. Suleymanova is looking for things in common in the works of the Circassians of the metropolis and the diaspora through the use of images of the Caucasian mountains [12].

Despite the fact that researchers have long and repeatedly used the terms "ethnic painting", "national painting", "national art school", their unambiguous definitions do not exist. It is indisputable that "ethnic painting" is to a certain extent opposed to "contemporary art" whose general focus is the struggle against canons and classical techniques. Hence comes its fundamental unsystematic character and deliberate eclecticism. "Ethnic painting" is fundamentally humanistic, and contemporary art in its essence opposes humanistic ideals and generates dehumanization of art [8].

Could ethnic art be contemporary? The answer to the question is not simple. As soon as the traditional is presented in a complex encrypted or transformed version, it ceases to be called "ethnic" and is immediately renamed into "conceptual" or "receptive". Artists that move away from traditional ethnic topics and images cease to provide information through "ethnic text", do not fit into the "ethnic picture of the world". Probably, in order for a new artistic language to become "ethnic", time is required so that large groups of the population start perceiving such a language as "their own".

Considering regional specific features of fine art in the North Caucasus, I.M. Aganov writes: “. . . ethnic features are especially vividly represented in the style and less in conceptualfigurative models that underlie the artistic thinking of representatives of different ethnic groups, in genre structures and compositional schemes, which, nevertheless, have a supra-ethnic, regional character" [1, p. 206]. We cannot but agree with it. Indeed, living in the same country, in the foothills and mountains of the Caucasus, having similar weather conditions, types of economic activities, similar rituals, norms of behavior, costumes, musical instruments, etc., which have been established for centuries, the Circassians, the Balkars, the Karachay, the Ingush, etc. have a lot in common in the fine arts. This is all the more understandable since the culture of painting developed among the peoples of the North Caucasus at approximately the same Soviet time (mid-20th century) with the same tasks and ideological attitudes. In Turkey, artistic communities with the inclusion of the Circassians appeared at the turn of the 20th century, and until recently the Caucasian theme did not appear at all or was marginal.

Periodization of pictorial art. The art of Circassian artists of Russia and Turkey can be conveniently classified into two periods: before the collapse of the USSR and after it. For the Russian artists, the first period could be conceptualized as "national", the second period is focused on universal human and world values. For the Circassians of Turkey, contrariwise, the second period is characterized by a strong interest in the themes of the Adyghe past, in the embodiment of the nature of the North Caucasus, folk dances, traditional dress, etiquette forms of behavior, illustration of the Nart epic, etc.

Comparing the characters of the Circassian artists of the metropolis and of the diaspora, at the first stage of pictorial art development, we find more differences than similarities. The métier of the Circassian artists of Adygea is to serve their people and country. The métier of the Circassian artists of Turkey is self-expression, representation of their country in the world art space. At the second (post-Soviet) stage, the artists of the metropolis and of the diaspora develop an interest in each other, get acquainted in person or via correspondence, want to learn more about works of each other, thematic roll-overs and intersections appear. The paintings of the artists of Adygea began not only to be exhibited in Turkey, but also to be sold there.

At the first stage, the function of Adyghe artists in the Republic of Adygea is to preserve memory about the past of the ethnic group, to dem- 
onstrate ideal features of the peoples, to provide their transmission in the future. The function of the art of Circassian artists of Turkey is to represent the country at the international exhibitions, to demonstrate inclusion of Turkish artists into the European and world art space, to prove the commercial value of art products.

Standing for participation in international art master classes and art symposia, Ahmet Özel believes that in this way it will be possible to "realize your own existence, show your presence to the world around you". At the same time, he points out that forming cultural exchange with the Caucasus will help "to perceive our hidden treasures, concealed in our DNA and to understand our inner cultural background" [9, p. 198].

One may object that Felix Petuvash and Teuchezh Kat do not fit into the general portrait of the artists of Adygea. Petuvash's paintings were exhibited in Turkey, Jordan, Bulgaria, the Czech Republic; Kat's personal exhibitions were held in Turkey, Jordan, Israel, Georgia. Petuvash's works are characterized by a multi-genre nature and multiplicity of meanings. He is interested in philosophical and psychological topics. Kat travels a lot around different cities and countries. In his works, he reconstructs the colorful image of what he has seen, transferring the atmosphere and unique coloring of the new countries on the canvases (series "Hungary", "Bulgaria", "Yugoslavia", 'Turkey", "Jordan"). But these artists are the exception to the rule rather than the rule itself. And the main part of their oeuvre representation abroad fell on the post-Soviet period. Most of the Circassian artists received education in the USSR (Russia); their significance, reputation, popularity were formed within the country, which gave them an opportunity to realize their artistic potential and satisfy their personal ambitions, and formed their individual view of the world. It goes without saying that, after the collapse of the USSR and establishment of firm contacts with the Circassian diaspora in Turkey, Jordan and Syria, the Circassian artists received new demands and opportunities. Qualitative changes in the content and subjects of the pictorial art of Turkish Adyghes were also observed in the post-Soviet period. However, the differences of life worlds and religious practices of the Circassians of the metropolis and of the diaspora could not but affect the realization of seemingly similar topics and images. The head-on approach through the two hundred years of developing culture in different conditions is a very complicated process.

It stands to reason that the Turkish sociologist of Circassian origin Jemre Jade notes that the Circassians who returned to their historical homeland in Adygea are still called "Turkish Adyghes" in the host community and they try to maintain everyday contacts not with the local population, but with the same "returnees" and from the places in Turkey from which they themselves returned [4].

Re-Ceptualists. Speaking about the art of the Circassian artists of Russia, one cannot ignore the oeuvre of a group of artists, Re-Ceptualists (the term of Slava Len), whose prominent representatives are Ruslan Tsrimov and Arsen Guchapshev. Being the author of the new term, Slava Len also proposed a Manifesto of Re-Ceptualists. The new direction is proclaimed as the art of the Third Millennium. It declares the idea not to imitate anything or reflect anything, to reject art "in artistic images", and to assert semiotic art in signs and symbols (the language of signatures, symbols and hieratures); principles of non-linearity, holism, mythology, and sacredness [7]. In the KabardinoBalkarian Republic, followers of Ruslan Tsrimov appeared. In Adygea, on the contrary, the art of this trend remained not only outside the wide interest of the masses, but also outside the active museum interest. For all the time, in Adygea, there were only three Tsrimov and his students' exhibitions in the North Caucasian Branch of the State Museum of Oriental Art and one in the Picture Gallery.

In the oeuvre of the Circassian artists of Turkey in the last 20 to 30 years, one can find themes and plots related to the Nart topic, to images of traditional culture. A special place is given to the theme of the Caucasian War, which caused people's outflow to the territory of the Ottoman Empire. Such storylines are typical not only for Dug Aytek, who was born in Turkey and received education in Maykop, but also for other artists, who ever visited their historical homeland (see, for example, works "Azhagafa", "Ubykh" by Zayna ElSaid from Jordan; sculptures by Bezroko Kerametin; book illustrations by Farouk Kutlu and Zeynep Bezroko). However, we are still quite little familiar with the oeuvre of all Circassian authors in Turkey 
in order to draw final conclusions, but the intermediate result of the study is the following.

Conclusions. The obvious time difference between the formation of artists and Circassian artistic communities in Russia and in Turkey is about 50 years. For the art of the Circassian artists of the diaspora, it is the end of the 19th and early 20th centuries; for the Circassians of Russia, it is the middle of the 20th century. The artists of the North Caucasus are characterized by reliance on traditions, realistic images, desire to retain their roots, Nart legends, and focus on the heroes of the epic as ethnic ideals. The Adyghe artistic tradition established as a realistic school basing on traditional topics, storylines, images, traditional coloring, and sign symbolism. Artists were brought up and developed on pieces of Soviet and world art, presented in museums in Moscow, Leningrad and other large cities of the USSR and on replicas of world artworks. United in trade unions, the Circassian artists were protected by the state with orders, materials and certain social benefits.
Their compatriots in the diaspora, contrariwise, are characterized by a desire for constant novelty, a different vision of the world through characteristic sociocultural needs and attitudes towards global world trends. Study in European capitals, inclusion into language and artistic environment of Europe and America allowed many artists to do global exhibition activities, to find a stable financial position, to clearly focus on world artistic and consumer values. It is obvious that the collapse of the USSR changed the paradigm of artistic activity of the Circassians not only in their historical homeland but also in the diaspora.

In recent years, integration processes between the Circassian artistic communities of Adygea (Russia) and of Turkey have become more noticeable. These processes are based on ethnic history, mythology, folklore, customs and traditions. The work on the project "Cultural Diffusion of the Circassians of Russia and Turkey: Art History and Socio-Cultural Analysis" has just begun, and answers to the questions posed at the beginning of this article are yet to be found.

Alla N. SOKOLOVA

Dr. Sci. (Musical Art), Prof., Institute of Arts, Adyghe State University, Maykop, Russian Federation, professor_sokolova@mail.ru

\section{Similarities and Differences in Oeuvre} of Circassian Artists of Adygea and Circassians of Turkey

Abstract. The study aims to identify and analyze the general and special characteristics of the works of the Circassian artists of Adygea and their colleagues from the Adyghe diaspora in Turkey. The sources were works of fine art, the results of research by domestic and Turkish art historians, critics, sociologists, and historians. The methodology is based on a combination of comparative techniques used in art history to analyze artistic objects and systems (synchronic and diachronic methods, microand macro-comparison). The social function of masters of painting living in different sociocultural conditions is studied, the goals of their work are revealed, priority genres and techniques are analyzed. The importance of the Adyghe artists who lived and live in the North Caucasus, as representatives of the artistic elite of the ethnic group, is emphasized; their work is aimed at preserving mythopoetic images and ethnic identity. Other tendencies are revealed in the creative experience of the Circassian artists of Turkey, who seek not only and not so much to reveal the culture of their people, but to turn to universal values, trying to integrate into the system of European and world art. The author identifies two periods in the development of the fine arts of Circassian artists in Russia and Turkey: before the collapse of the USSR and after it. The characteristic features of the oeuvre of representatives of both groups of artists during the periods identified are revealed. The activity of contemporary artists-receptivists of Adyghe origin (R. Tsrimov and A. Guchapshev and others) is especially highlighted. The basic artistic 
principles of receptivism are given, and, in a comparative aspect, the degree of popularity of this trend in Kabardino-Balkaria and Adygea is revealed. It is concluded that the differences between the Adyghe artists of Russia and Turkey are manifested in several aspects: at the moment of the formation of the Adyghe art communities in Turkey and in Russia; in the peculiarities of the formed and maintained artistic tradition; in unequal conditions of obtaining professional education by masters of the Caucasus and Turkey; in the socioeconomic circumstances that determined the creative activity and indirectly influenced the value orientations of artists. The points of creative intersection lie in the plane of ethnic values, signs and symbols, equally deciphered by the Circassians of the North Caucasus and the diaspora, as well as in assessments of the historical past, especially the Caucasian War, in a particularly revered attitude towards the nature and beauty of the Caucasus.

Keywords: the Adyghes, the Circasssians, metropolitan artists, diaspora, worldview, roles of artists, signs and symbols of art, aesthetic dominants, priority genres, similarity and difference in oeuvre of Circassian artists.

\section{Использованная литература:}

1. Aganov I. M. Izobrazitel'noe iskusstvo kak etnokul'turnyy fenomen [Fine arts as ethnocultural phenomenon] // Vestnik Adygeyskogo gosudarstvennogo universiteta. Seriya 1: Regionovedenie: filosofiya, istoriya, sotsiologiya, yurisprudentsiya, politologiya, kul'turologiya» [The Bulletin of Adyghe State University. Ser. 1. Regional Studies: Philosophy, History, Sociology, Jurisprudence, Political Sciences and Culturology]. № 1 (156). Maykop, 2015. pp. 205-210.

2. Appaeva Zh. Stanovlenie izobrazitel'nogo iskusstva Kabardino-Balkarii [Formation of the fine arts of KabardinoBalkaria] [Electronic resource] // Morozovskie Chteniya: Mezhdunarodnaya nauchnaya konferentsiya (Moskva, 24-25 noyabr. 2011 g.) [Morozov Readings: International Scientific Conference (Moscow, November 24-25, 2011)]. URL: https://www.ais-aica.ru/239-2011-01-21-10-03-12/-2011110/2581-2011-12-29-10-37-00.html (date of access: 12.10.2020).

3. Bazieva G. D. Mifologizm i fol'klorizm v khudozhestvennoy kul'ture Kabardino-Balkarii [Mythologism and folklorism in art culture of Kabardino-Balkaria] // Vestnik Tambovskogo gosudarstvennogo universiteta. Gumanitarnye nauki. Filosofiya, sotsiologiya i kul'turologiya. [The Bulletin of Tambov State Unversity. Social Science. Philosophy, sociology and cultural studies]. № 8 (76). Tambov, 2009. pp. 188-192.

4. Jade C. E. Adygo-abkhazskaya diaspora i repatriatsiya iz Turtsii v Abkhaziyu i Adygeyu [AdygheAbkhazian diaspora and repatriation from Turkey to Abkhazia and Adygheya]. Maykop: Poligraph-Yug, 2020.

5. Kochesokova L. P. Stanovlenie professional'nogo izobrazitel'nogo iskusstva Kabardino-Balkarii [Formation of professional fine arts in Kabardino-Balkaria] // Kul'turnaya zhizn' Yuga Rossii [Cultural life of the South of Russia]. 2010. №. 3 (37). pp. 23-24.

6. Kruglyy stol “Sovremennoe izobrazitel'noe iskusstvo cherkesov (adygov): poiski natsional'nogo $\mathrm{v}$ global'nom kontekste" (Maykop, 6 iyulya 2020 g.) [Round table "Modern art of the Circassians (Adyghes): searches of the national within theglobalcontext" (Maykop, July 6, 2020)] [Electronic resource] // Severokavkazskiy filial Gosudarstvennogo

\section{References:}

1. Aganov, I.M. (2015) Fine Arts as Ethnocultural Phenomenon. Vestnik Adygeyskogo gosudarstvennogo universiteta. Seriya 1: Regionovedenie: filosofiya, istoriya, sotsiologiya, yurisprudentsiya, politologiya, kul'turologiyaBulletin of the Adyghe State University. Series 1: Region Studies: Philosophy, History, Sociology, Jurisprudence, Political Sciences and Culturology. 1 (156). pp. 205-210. (In Russian).

2. Appaeva, Zh. (2011) [Formation of the Fine Arts of Kabardino-Balkaria]. Morozovskie chteniya [Morozov Readings]. Proceedings of the International Conference. Moscow. 24-25 November 2011. [Online] Available from: https://www.ais-aica.ru/239-2011-01-21-10-03-12/2011110/2581-2011-12-29-10-37-00.html (Accessed: 12.10.2020).

3. Bazieva, G.D. (2009) Mifologizm i fol'klorizm v khudozhestvennoy kul'ture Kabardino-Balkarii [Mythologism and Folklorism in the Artistic Culture of Kabardino-Balkaria]. Vestnik Tambovskogo gosudarstvennogo universiteta. Gumanitarnye nauki. Filosofiya, sotsiologiya i kul'turologiya - Tambov University Review. Series: Humanities. 8 (76). pp. 188-192.

4. Jade, J.E. (2020) Adygo-abkhazskaya diaspora i repatriatsiya iz Turtsii v Abkhaziyu i Adygeyu [The AdygheAbkhaz Diaspora and Repatriation from Turkey to Abkhazia and Adygea]. Maykop: Poligraf-Yug.

5. Kochesokova, L.P. (2010) Formation of Professional Fine Arts in Kabardino-Balkaria. Kul'turnaya zhizn' Yuga Rossii - Cultural Studies of Russian South. 3 (37). pp. 23-24. (In Russian).

6. North Caucasian Branch of the State Museum of Oriental Art. (2020) Kruglyy stol "Sovremennoe izobrazitel'noe iskusstvo cherkesov (adygov): poiski natsional'nogo $v$ global'nom kontekste" [Round Table "Contemporary Fine Art of the Circassians (Adyghe People): The Search for the National in a Global Context"]. Maykop. 6 July 2020. [Online] Available from: http://orientmuseum-filial.ru/newsfeed/ kruglyj-stol-sovremennoe-izobrazitelnoe-iskusstvo(Accessed: 12.10.2020). 
muzeya Vostoka [North Caucasian Branch of The State Museum of Oriental Art]. URL: http://orientmuseum-filial. $\mathrm{ru} /$ newsfeed/kruglyj-stol-sovremennoe-izobrazitelnoeiskusstvo- (date of access: 12.10.2020).

7. Len, S. Re-Tseptual'nyy serial $v$ kontekste postmodernizma [Receptual series in the context of postmodern]. Nalchik: El-Fa, 2005.

8. Ortega y Gasset J. Degumanizatsiya iskusstva [The Dehumanisation of Art]. M.: Raduga, 2000.

9. Özel A. Art in life and creativity of Circassians of Turkey // Obrazy, syuzhety, khudozhestvennye napravleniya v izobrazitel'nom iskusstve: regional'nyy aspekt [Images, plots, artistic trends in the visual arts: regional aspect] / Ed. by A. N. Sokolova. Maykop: Magarin O.G., 2020.

10. Sokolova A. N. Nartskie obrazy $v$ tvorchestve khudozhnikov Adygei [Nart characters in the oeuvre of Adyghe artists] // Severnyy Kavkaz: iskusstvo v kontekste vremeni. Materialy mezhdunarodnoy nauchnoy konferentsii (Maykop, 9-11 oktyabrya 2015) [North Caucasus: art in the context of time: Materials of the international scientific conference (Maykop, October 9-11, 2015)]. Maykop: Grafika, 2015. pp. 106-113.

11. Sokolova A. N. Nartiada v kontekste sovremennoy kul'tury regiona [Nartiada in the context of modern culture of the region] // Vestnik Adygeyskogo gosudarstvennogo universiteta. Seriya 2: Filologiya i iskusstvovedenie [The Bulletin of Adyghe State Unversity. Series 2: Philology and Art Criticism]. № 3 (164). Maykop, 2015. pp. 149-156.

12. Suleimanova F. Kh. Gornyy peyzazh Severnogo Kavkaza kak osnova formirovaniya khudozhestvennykh obrazov v sovremennom iskusstve cherkesskikh khudozhnikov Rossii i Turtsii [Mountain landscape of the North Caucasus as the basis for the formation of artistic images in the contemporary art of Circassian artists of Russia and Turkey] // Vestnik Adygeyskogo gosudarstvennogo universiteta. Seriya 2: Filologiya i iskusstvovedenie [The Bulletin of Adyghe State Unversity. Series 2: Philology and Art Criticism]. №. 2 (257). Maykop, 2020. pp. 171-182.

13. Tertyshnik N. B. Natsional'noe i internatsional'noe $\mathrm{v}$ dekorativno-prikladnom iskusstve khudozhnikov Adygei [The national and international in arts and crafts of Adygheya artists] // Vestnik Adygeyskogo gosudarstvennogo universiteta. Seriya 1: Regionovedenie: filosofiya, istoriya, sotsiologiya, yurisprudentsiya, politologiya, kul'turologiya» [The Bulletin of Adyghe State University. Ser. 1. Regional Studies: Philosophy, History, Sociology, Jurisprudence, Political Sciences and Culturology ]. № 1. Maykop, 2012. pp. 255-259.
7. Len, S. (2005) Re-Tseptual'nyy serial v kontekste postmodernizma [Re-Ceptual Serial in the Context of Postmodernism]. Nalchik: El-Fa.

8. Ortega y Gasset, J. (2000) Degumanizatsiya iskusstva [The Dehumanization of Art]. Translated from Spanish. Moscow: Raduga.

9. Özel A. (2020) Art in Life and Creativity of Circassians of Turkey. In: Sokolova, A.N. (ed.) Obrazy, syuzhety, khudozhestvennye napravleniya $v$ izobrazitel'nom iskusstve: regional'nyy aspekt [Images, Plots, Art Trends in the Fine Arts: A Regional Aspect]. Maykop: Magarin O. G.

10. Sokolova, A.N. (2015) [Nart Images in the Works of the Artists of Adygea]. Severnyy Kavkaz: iskusstvo v kontekste vremeni [North Caucasus: Art in the Context of Time]. Proceedings of the International Conference. Maykop. 9-11 October 2015. Maykop: Grafika. pp. 106-113. (In Russian).

11. Sokolova, A.N. (2015) Nartiada in the Context of Modern Culture of the Region. Vestnik Adygeyskogo gosudarstvennogo universiteta. Seriya 2: Filologiya $i$ iskusstvovedenie - Bulletin of the Adyghe State University. Series 2: Philology and the Arts. 3 (164). pp. 149-156. (In Russian).

12. Suleymanova, F. Kh. (2020) Mountain Landscape of the North Caucasus as the Basis for the Formation of Artistic Images in the Contemporary Art of Circassian Artists of Russia and Turkey. Vestnik Adygeyskogo gosudarstvennogo universiteta. Seriya 2: Filologiya i iskusstvovedenie - Bulletin of the Adyghe State University. Series 2: Philology and the Arts. 2 (257). pp. 171-182. (In Russian).

13. Tertyshnik, N.B. (2012) The National and International in Arts and Crafts of Adygea Artists. Vestnik Adygeyskogo gosudarstvennogo universiteta. Seriya 1: Regionovedenie: filosofiya, istoriya, sotsiologiya, yurisprudentsiya, politologiya, kul'turologiya - Bulletin of the Adyghe State University. Series 1: Region Studies: Philosophy, History, Sociology, Jurisprudence, Political Sciences and Culturology. 1. pp. 255-259. (In Russian).

\section{Полная библиографическая ссылка на статью:}

Sokolova, A. N. Similarity and Difference in Oeuvre of Circassian Artists of Adygheya and Circassians of Turkey [Общее и особенное в творчестве черкесских художников Адыгеи и черкесов Турции] / A. N. Sokolova // Наследие веков. - 2020 - № 4 - С. 37-45. DOI: 10.36343/SB.2020.24.4.003

\section{Full bibliographic reference to the article:}

Sokolova, A. N. (2020) Similarities and Differences in Oeuvre of Circassian Artists of Adygea and Circassians of Turkey. Nasledie vekov - Heritage of Centuries. 4. pp. 37-45. (In Russian). DOI: 10.36343/SB.2020.24.4.003 